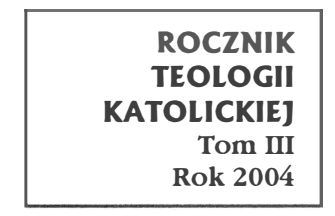

\title{
SYNOD BISKUPA ALEKSANDRA KOTOWICZA Z 1685 R.
}

\author{
Oprac. ks. Andrzej Kakareko
}

Biskup Aleksander Kotowicz rządził diecezją wileńską bardzo krótko. Jego rządy przypadają na lata 1685-1686. Już trzeciego dnia po ingresie biskup Kotowicz rozpoczął synod diecezjalny, który trwał trzy dni. Uchwały tego synodu zostały ogłoszone drukiem i zawierają 41 nienumerowanych statutów, traktujących o sprawach szeroko rozumianej dyscypliny kościelnej i duszpasterstwa. Dekrety poprzedza przedmowa dedykacyjna kanclerza diecezji wileńskiej a zarazem dyrektora synodu, księdza Jana Woronowicza oraz dekret promulgacyjny biskupa Kotowicza. Wśród statutów są artykuły nowe, niespotykane w poprzednich synodach, jak te traktujące o cudownych obrazach i patronach diecezji ${ }^{1}$. Także wiele innych, szczególnie w sprawach dotyczących duchowieństwa, zawiera rozwiązania, których nie ma we wcześniejszych synodach diecezji wileńskiej. Choć z punktu widzenia techniki legislacyjnej synod ten nie należy do dzieł wybitnych, $\mathrm{z}$ racji na nowe i oryginalne treści zasługuje na uwagę.

\section{Zwołanie i przebieg synodu}

Synod odbył się w dniach 1-3 października 1685 r. (data 1-3 wr'ześnia 1685 r., podana na karcie tytułowej drukowanego wydania, jest niewątpliwie błędem drukarskim)². O odbyciu omawianego synodu diecezjalnego donoszą akta kapituły wileńskiej: „W dzień św. Michała Aleksander Kotowicz, bp wileński, objął w swoją posesję katedrę; na trzeci dzień po objęciu synod diecez-

1 T. Krahel, Zarys dziejów (archi)diecezji wileńskiej, „Studia Teologiczne” 1987-1988, nr 5-6, s. 43.

? Por. J. Sawicki, Concilia Poloniae. Źródta i studia krytyczne II. Synody diecezji wileńskiej i ich statuty, Warszawa 1948, s. 91-92. 
jalny... przez 3 dni odprawił i zakończył”’. W punktach przedstawionych kapitule biskup poruszył sprawy katedry wileńskiej, domagając się m.in. więcej kleryków z seminarium do obsługi katedry, powiększenia liczby wikariuszy katedralnych i grona duchowieństwa katedralnego poprzez przekazanie beneficjów oraz altarii katedralnych innym duchownym, którzy takich beneficjów nie posiadali. ${ }^{4}$

Oprócz biskupa wileńskiego, w synodzie uczestniczyli biskupi sufragani, członkowie kapituły, duchowieństwo katedralne i diecezjalne ${ }^{5}$. Na otwarcie synodu mowę wygłosił Eustachy Kotowicz, w której powołując się na Ojców Kościoła i teksty Pisma św. podkreślał godność kapłaństwa i przywoływał cnoty, jakie powinny wyróżniać prawdziwego duszpasterza: proste i cnotliwe życie, współczucie, roztropność, właściwy stosunek do wszystkich wiernych bez względu na płeć, stan czy sytuację majątkową ${ }^{6}$. Drugiego dnia synodu mowę wygłosił Jan Piątkowski. Zwrócił uwagę na obowiązek zabiegania o dobro wiernych i ich właściwą formację; podkreślił i szeroko omówił dwie zasadnicze cnoty, które stanowią fundament „Królestw i Repubik” - zatroskanie i wierność 7 .

\section{Treść uchwał synodalnych}

(1) De miraculosis Imaginibus (k. 2) - Artykuł ogłoszony na prośbę kapituły postanawia, aby obrazy świętych, a zwłaszcza Matki Boskiej, nie były wystawiane ludowi jako cudowne, dopóki nie zostaną zatwierdzone do kultu po uprzednim zbadaniu ich pochodzenia, starożytności i cudowności.

(2) De Patronis huius Diaecesis \& aliorum solenniter Celebrandis Festis ad populum - Ogłoszony również na prośbę kapituły statut zaleca, aby w całej diecezji dzień narodzenia św. Jana Kantego, wyznaczony przez Stolicę Apostolską, był obchodzony w całej diecezji jako święto patronalne. Na usilną prośbę prowincjała augustianów Melchiora Nyżyńskiego oraz Michała Rusieckiego, prepozyta kanoników regularnych, nakazano w najbliższą pierwszą niedzielę września obchodzić w całej diecezji wspomnienie św. Augustyna biskupa, zaś na prośbę opata trockiego Jana Chryzostoma Zygmunta Zdrowskiego, ksieni benedyktynek Franciszki Emerantiany Gałeckiej oraz innych godnych osób polecono uroczyście ludowi odprawiać wspomnienie św. Benedykta w dniu 21 marca, a św. Scholastyki w najbliższą niedzielę wypadającą po dniu jej narodzenia.

\footnotetext{
${ }^{3}$ Tamże, s. 91.

${ }^{4} \mathrm{~J}$. Kurczewski, Kościót zamkowy czyli katedra wileńska w jej dziejowym, liturgicznym, architektonicznym i ekonomicznym rozwoju, t. 1, Wilno 1908, s. 168.

${ }^{5}$ Zob. J. Sawicki, Concilia Poloniae, dz. cyt., s. 87-88.

${ }^{6}$ Acta, Constitutiones et Decreta Synodi Vilnensis, Praesidente Illustrissimo Ac Reverendissimo Domino Domino Alexandro Michaele Kotowicz Dei et Apostolicae Sedis Gratia Episcopo Vilnensi Almae Vilnensis Accademiae Cancelario, Anno Domini Millesimo Seicentesimo Octogesimo Quinto, Die Ima, 2da et 3tia Mensis Septembris Celebrate. Typis Academicis Impressa Anno ut supra (1685), k. 38-46.

${ }^{7}$ Tamże, k. 46-54.
} 
(3) De Prothonotariis Apostolicis \& vsu Mantelleti - Z uwagi na to, że niektórzy duchowni, wbrew prawu kanonicznemu, dla samego tylko prawa noszenia mantoletu, bez egzaminu, poprzez własne i źle uzasadnione zabiegi niezasłużenie otrzymują godność protonotariusza apostolskiego, chociaż pod karą arbitralną i groźbą pozbawienia mantoletu zabrania się ubiegania się w Stolicy Apostolskiej o tę godność bez egzaminu i pism rekomendacyjnych biskupa. Przypomniano, że prawo noszenia mantoletu posiadają wyłącznie protonotariusze „de numero”. Z uwagi na godność kapituły wileńskiej, zabroniono wszystkim innym protonotariuszom używania mantoletu „tak w mieście, jak i poza jego murami” bez specjalnego zezwolenia biskupa. Czuwać nad tym miał inwestygator z prawem pozwania takiego i ukarania. Kanonikom kapituły smoleńskiej zabroniono bezprawnego noszenia rokiety na terenie diecezji wileńskiej, jeśli nie posiadają zezwolenia Stolicy Apostolskiej. Prałatów i kanoników pochodzących z innych diecezji zobowiązano do przedstawienia dokumentów potwierdzających posiadanie przywileju i uzyskania pisemnej zgody biskupa do noszenia rokiety w katedrze wileńskiej i poza katedrą. Na wszystkich protonotariuszy nałożono obowiązek przedstawienia dokumentu, potwierdzającego otrzymanie godności w przeciągu trzech miesięcy od jej przyznania. Ci, którzy do tego czasu nie okażą przywileju, nie mają prawa noszenia stroju przysługującego protonotariuszom. Zadanie to powierzono kanclerzowi diecezji.

(4) De Parochis \& quibusvis Presbyteris saecularibus Vilnae per modum hospitum commorantibus (k. 5-6) - Nakazano duchownym przybywającym do Wilna zgłoszenie w kurii miejsca zamieszkania i bez osobistego zameldowania się biskupowi zabroniono odprawiania Mszy św. Pod karą arbitralną, zastrzeżoną biskupowi, duchownym przebywającym w Wilnie nakazano, aby przy sprawowaniu świętych obrzędów w katedrze lub w innym kościele nakładali czyste komże. W artykule tym zwrócono uwagę zatrzymującym się w zajazdach, by postępowali w sposób nie uwłaczający godności kapłańskiej.

(5) De Presbyteris pridem \& noviter ordinatis (k. 6-7) - Ponieważ wyświęceni na podstawie prowizji prezbiterzy dla zysku lub pod pretekstem studiów w Akademii Wileńskiej pozostawali w Wilnie i nie mając jurysdykcji rozgrzeszali z rezerwatów papieskich i biskupich oraz spowiadali zakonnice, nakazano nowo wyświęconym bezzwłoczne udanie się do wyznaczonych im parafii. Opornym zagrożono karą więzienia, zaś słuchającym spowiedzi suspensą zastrzeżoną biskupowi i pod rygorem nieważności rozgrzeszenia. Zakonnikom zakazano korzystania z pomocy księży diecezjalnych, którzy nie otrzymali specjalnego zezwolenia. Aby lepiej przygotować kler diecezjalny do sprawowania liturgii, zalecono klerykom, aby pod okiem ceremoniarza i wicedziekana służyli w katedrze. Ćwiczenia te kończyłby egzamin dopuszczający do dalszych święceń.

(6) De non admittendis Presbyteris ad Benefitia curata \& simplicia ex alienis Diaecesibus (k. 8-9) - W celu obrony praw i dochodów miejscowego duchowieństwa, synod zabronił przyznawać beneficjów duchownym pochodzącym z obcych diecezji, gdyż „miejscowi są w dostatecznej liczbie i wystarczają- 
co wykształceni”. Kolatorów i patronów kościołów napomniano, że wyznaczeni przez nich obcy duchowni nie otrzymają instytucji kanonicznej. Gdyby w przeciągu sześciu miesięcy nie został wyznaczony miejscowy duchowny, prawo to przechodziło na biskupa.

(7) De vita \& honestate Cleri Diaecesani (k. 9) - Artykuł powtarza postanowienia prawa powszechnego dotyczące tonsury i stroju duchownych: zabrania noszenia długich włosów, brody, zbyt wyszukanego stroju, pierścienia (pod karą konfiskaty) i broni, zakazuje trzymać na plebanii „kobiety podejrzane", grę w karty na pieniądze oraz przyjmowania urzędów u świeckich, m.in. funkcji kapelana, bez zgody biskupa, zaleca nosić sutannę, żyć skromnie i unikać karczm, czas poświęcać na modlitwę i medytację doktryny chrześcijańskiej.

(8) De pluritate Beneficiorum (k. 10) - Przepis przywołuje potrydencki zakaz łączenia dwóch beneficjów rezydencjalnych bez zgody Stolicy Apostolskiej (Conc. Trident., sess. 24, c. 7) i bez specjalnego zezwolenia zabrania duchownym sprawować w nich duszpasterstwo pod karą pozbawienia beneficjum.

(9) De Residentia circa Benefitia Ecclesiastica (k. 10-11) - Powołując się na święte kanony postanowiono, iż beneficjaci, którzy przez sześć miesięcy od ogłoszeniu dekretu nie powrócą do parafii, w której mają obowiązek rezydować, zostaną pozbawieni beneficjum. Proboszczom, którzy w interesach ze szkodą dla dusz udają się do Rygi, Królewca, Gdańska lub innych miejscowości poza diecezją, zabroniono opuszczać parafię bez pisemnego zezwolenia i po zapewnieniu godnego zastępcy.

(10) De Altaristis in Ecclesiis Parochrorum (k. 11-12) - W statucie tym zwraca się uwagę, aby duchowni posiadający altarie lub prebendy sprawowali należycie swoją posługę i zachowywali rezydencję przy swoich kościołach. Synod zachęca ich, aby w duchu braterskiej miłości wspierali proboszczów w spowiadaniu wiernych i sprawowaniu innych sakramentów pod karą utraty czwartej części dochodów na rzecz kościoła, w którym pełnią posługę bez jakiegokolwiek procesu sądowego.

(11) De Celebratione Divinorum in Ecclesiis per praelatos \& Canonicos alterius Diaecesis (k. 12) - Zdarza się często, że prałaci i kanonicy z innych kapituł pod pretekstem posiadanych przez siebie przywilejów i godności odprawiają uroczyste nieszpory i msze $\mathrm{z}$ dnia następnego przy udziale duchowieństwa i w ten sposób naruszają prawa biskupów i pomniejszają znaczenie ich celebry. Dlatego synod, dla ukrócenia tych nadużyć, nakazuje pod karami, aby nieszpory odprawiali oni w asyście czterech kleryków ubranych w alby lub dwóch akolitów, zaś mszę św. razem z diakonem i subdiakonem w dalmatykach. Pozostałym duchownym uczestniczącym w nieszporach i Mszy św. nakazano nakładać tylko komże (zabroniono zakładania kapy).

(12) De non celebrandis Missis in Aedibus piuatis (k. 13) - Artykuł ten, będący powtórzeniem paralelnego zapisu synodu wileńskiego z 1669 r., jest reakcją na często spotykane nadużycie, którego dopuszczali się przede wszystkim zakonnicy, odprawiając Msze św. w domach prywatnych. Zawiera 
on apel do władz zakonnych, aby podjęły stosowne działania w celu ukrócenia samowoli ich podwładnych.

(13) De Examinatoribus Synodalibus ad Beneficia curata \& Confessiones Sacramentaliter excipiendas (k. 13-14) - Statut ten ustanawia egzaminatorów synodalnych: Mikołaja Słupskiego, Eustachego Kotowicza, Jana Kriszpina Kierszeysztena, Jana Piątkowskiego, Jana Woronowicza i Teodora Mentyckiego. Do ich obowiązków, zgodnie z postanowieniami Soboru Trydenckiego, należało egzaminowanie kandydatów na beneficja dla sprawdzenia ich zdatności do spowiadania wiernych.

(14) De Censoribus librorum imprimendorum (k. 14) - Statut ustanawia cenzorami ksiąg Eustachego Kotowicza i Mikołaja Jana Zgirskiego.

(15) De revisione librorum in Bibliothecis venalium (k. 14-15) - Zgodnie $\mathrm{z}$ postanowieniem synodu prowincjonalnego ustanowiono rewizorami ksiąg Jana Piątkowskiego i Jana Woronowicza ${ }^{8}$.

(16) De Conseruatoribus Religiosorum ordinum (k. 16) - Ponieważ na synodzie żaden z zakonów nie wybrał dla siebie konserwatorów i o ustanowienie takowych nie wystąpił, „z powodu ich uporu” konserwatorów nie ustanowiono.

(17) De Schola \& Cantu (k. 15-16) - Powołując się ogólnie na postanowienia synodu prowincjonalnego, synod poleca wszystkim proboszczom, aby zakładali przy parafiach szkoły, w których chłopcy uczyliby się podstaw czytania, pobożności i śpiewu kościelnego. Pod karami arbitralnymi nakazano zatrudnić godnych i zdolnych bakałarzy.

(18) De Oleis Sacris (k. 16) - Z powodu skarg proboszczów, którzy ze względu na odległość lub brak pieniędzy nie są w stanie w czasie wielkanocnym przyjechać po nowe oleje, synod nakazuje dziekanom, aby w okresie jednego miesiąca zaopatrywali się w katedrze u wicekustosza w oleje święte dla wszystkich kościołów swojego dekanatu (za potwierdzeniem odbioru) i przekazywali je proboszczom „salvo salario competente”, odpowiednio do drogi i z racji na opłaty wniesione wicedziekanowi katedry.

(19) De Communione Paschali \& festis solemnibus tempore Messis (k. 17) - Na prośbę duchowieństwa, które z powodu licznego napływu wiernych nie jest w stanie należycie wyspowiadać wszystkich wiernych, do sześciu tygodni postanowiono przedłużyć czas komunii wielkanocnej, zaś uroczystości przypadające w czasie żniw pozwolono przenieść na najbliższą wolną niedzielę „intra spatium unius anni”.

(20) De Testamentis Presbyterorum (k. 17-18) - Z uwagi na to, że niektórzy duchowni w swoich testamentach nie pamiętają o własnym kościele, przekazując dobra ruchome i pieniądze zakonom czy jeszcze za życia czyniąc im darowizny (nie bez nakłaniania ze strony zakonników), synod postanawia, aby trzecia część majątku była zapisana na kościół lub inne beneficjum pod

\footnotetext{
${ }^{8}$ Statuty synodu prowincjonalnego warszawskiego z 1643 r.: art. (37) Librorum approbatio \& Bibliothecarum revisio. Zob. J. Sawicki, Concilia Poloniae, dz. cyt., s. 89.
} 
sankcją nieważności donacji lub testamentu. Decyzja w tej sprawie należy do biskupa, zgodnie z konstytucjami prowincjonalnymi. ${ }^{9}$ Ponieważ wielu duchownych nie sporządza testamentu lub nie wie, jak go sporządzić, synod nakazuje zachowywać w tej materii postanowienia konstytucji synodalnych.

(21) De Testamentis \& Eorum Forma (k. 18-20) - W artykule tym zaleca się, aby ostatnia wola dotycząca przekazania dóbr na cele pobożne była wyrażana wobec dwóch kapłanów lub innych dwóch wiarygodnych świadków, zaś na inne cele, wobec proboszcza i dwóch świadków lub czterech, gdyby proboszcz nie chciał lub nie mógł być obecnym. Tak wyrażony akt ostatniej woli winien być własnoręcznie spisany przez testatora lub kogoś innego. Na końcu artykuł podaje wzór testamentu.

(22) De Suffragiis pro Animabus defunctorum ex Clero (k. 20-21) - Powołując się na statuty synodu Sapiehy, synod postanawia, aby każdy „curatus et non curatus”, gdy dowie się o śmierci jakiegoś duchownego „przy biciu dzwonów" odprawił za jego duszę trzy Msze św. i jego duszę polecił z ambony modlitwie wiernych. Za wszystkich wiernych polecono odprawianie jednej mszy w miesiącu. Powiadamianie o śmierci duchownego synod powierzył trosce dziekanów, a szczególnie kanclerza.

(23) De Ecclesia Parochiali Antokollensi (k. 21-22) - W statucie tym potwierdza się granice pomiędzy parafią na Antokolu a parafią kanoników regularnych oraz wylicza się tereny i miejscowości, które do niej należą, i które należy jej zwrócić.

(24) De Ecclesia Pivoszunensi (k. 22) - Statutem tym kościół w Piwoszunach zostaje przekazany pod duszpasterstwo parafii Daugi.

(25) De Arendatione bonorum Ecclesiasticorum \& oppignorationibus (k. 22-23) - W trosce o stan dóbr kościelnych nakazuje się proboszczom i posiadającym beneficja proste, aby bez zgody biskupa i po przedstawieniu mu sprawy nie zastawiali własności kościelnej. Dla potrzeb prywatnych zabroniono zastawiania złotych i srebrnych naczyń kościelnych, krzyży i wotów oraz innych przedmiotów, zwłaszcza Żydom i innym sekciarzom. Gdyby ktoś tak postąpił, ma obowiązek odzyskać zastawione przedmioty pod karą ekskomuniki i pozbawienia beneficjum. Synod upomina udzielającym zastawu, że są zobowiązani do zwrócenia zastawionych przedmiotów po oddaniu długu i przestrzega ich, iż w razie potrzeby inwestygator może podjąć wobec nich działania ,in foro spirituali”.

(26) De Casibus reservatis Ordinariae sedi (k. 23-24) - Statut ten zawiera wykaz 12 rezerwatów zastrzeżonych biskupowi: zaniedbywanie rezydencji, zaniedbywanie pobożnych legatów, krzywoprzysięstwo w sądzie, sfałszowanie pieczęci i podpisu, poświadczenie nieprawdy w sądzie lub na piśmie na forum pozasądowym, przestępstwo sodomii, bestialstwa i kazirodztwa z powinowatą lub krewną w pierwszym stopniu, zgwałcenie kobiety, aborcja, porwanie niewiasty lub cudzej małżonki, zabójstwo lub podżeganie do zabój-

\footnotetext{
9 Zbiór Wężyka, wyd. 1630, s. 173n. Zob. J. Sawicki, Concilia Poloniae, dz. cyt., s. 89.
} 
stwa, przemoc wobec rodziców i podpalenie, czary, otrucie, czarnoksięstwo, udzielanie i sprzyjanie rozwodom.

(27) De Exorcistis (k. 24) - Synod zabrania dokonywania egzorcyzmów bez egzaminu i aprobaty biskupa.

(28) De abusu Patenae osculi post Missam (k. 24-25) - W artykule tym upomina się zwłaszcza kapelanów, aby po każdej Mszy św. nie dawali pateny do całowania świeckim, w tym kobietom, pod karą suspensy ipso facto na okres jednego miesiąca i innymi karami według uznania właściwych przełożonych. Ten honor, co zaznacza synod, przysługuje tylko biskupom, prałatom i kanonikom oraz cieszącym się godnością senatorską. W związku z tym synod apeluje do przełożonych zakonnych, aby zwracali uwagę na przestrzeganie powyższego zakazu.

(29) De Mercibus Sylvestribus (k. 25-26) - Ponieważ docierały wieści, iż niektórzy proboszczowie wycinają lasy i drewno spławiają do Rygi i Królewca, aby zapobiec dewastacji lasów, synod zabrania podejmowania takich przedsięwzięć bez wyraźnej zgody biskupa, po przedstawieniu powodów i pod warunkiem, że uzyskane stąd pieniądze będą obrócone na pożytek kościoła.

(30) De Officio \& obligatione singulari Decanorum (k. 26) - Dziekanom przypomniano, aby przy okazji zebrań dekanalnych i wizytacji dziekańskich dokładnie sprawdzali, czy dekrety reformacyjne wydane przez wizytatorów są na czas wykonywane. W wypadku zaniedbań ze strony proboszczów, dziekani mają obowiązek takich denuncjować. Sumieniu dziekanów polecono baczyć, czy duchowieństwo należycie płaci podatki i wypełnia inne obowiązki wobec Rzeczpospolitej.

(31) De Constitutionibus Synodalibus Diaecesanis (k. 26-27) - Uroczyście potwierdzono i przypomniano statuty synodu biskupa Aleksandra Sapiehy z 1669 r. Nakazano przestrzegać przepisów tego i obecnego synodu. Proboszczów zobowiązano do nabycia akt tych synodów pod groźbą ciężkich kar, gdyby podczas wizytacji generalnej okazało się, że ich nie posiadają.

(32) De Contributione pro Tecto Ecclesiae Cathedralis Vilnensis (k. 27) - Z powodu braku funduszy kapitulnych na skutek zniszczeń wojennych, na każdy kościół parafialny nałożono podatek na remont dachu katedry wileńskiej w wysokości 15 groszy od każdego dymu, z obowiązkiem zapłacenia go w okresie czterech miesięcy.

(33) De Religiosis involantibus in Iura Parochorum (k. 28) - Ponieważ w Wilnie ojcowie zakonni nie zawsze respektują prawa parafialne i nie posiadając takich uprawnień wprowadzają do swoich kościołów niewiasty po dopełnieniu małżeństwa i po porodzie oraz udzielają sakramentów świętych, szczególnie namaszczenia chorych i ze szkodą dla proboszczów odprawiają Msze św. w kaplicach możnych, odciągając wiernych od ich kościołów, synod zabrania im udzielać sakramentów bez odpowiedniego zezwolenia pod karami przewidzianymi w prawie kanonicznym, chyba że zostaliby poproszeni przez proboszczów. Ponieważ kościół w Słonimiu ponosi wielkie szkody ze strony ojców kanoników regularnych, którzy tam prowadzą duszpasterstwo i udziela- 
ją sakramentów świętych, synod zaleca, aby rządca tego kościoła aż do skutku prowadził proces w celu egzekucji przysługujących mu praw.

(34) De Presbyteris saecularibus in servitiis Regularium Ecclesiarum existentibus (k. 29) - Dla ochrony godności księży diecezjalnych posługujących w kościołach zakonnych, którzy z powodu złego traktowania samowolnie opuszczają parafię, synod zabrania duchownym diecezjalnym podejmowania posługi w tych kościołach bez wiedzy i zgody biskupa oraz instytucji kanonicznej pod karą suspensy a Divinis. Zgodnie z postanowieniami wcześniejszego synodu prowincjonalnego, zabroniono duchownym świeckim posługiwania w dalmatykach zakonnym celebransom oraz zakonnikom posługiwania duchownym świeckim pod karami według osądu biskupa ${ }^{10}$.

(35) De Officinis apertis Negotiatorum Diebus Dominicis \& festis (k. 30) - Aby wykorzenić handel w niedziele i święta nakazane, który ma miejsce w Wilnie, synod postanawia karać opornych handlarzy karą konfiskaty towaru na rzecz szpitali. Zadanie to powierzono urzędnikom magistratu wileńskiego. W innych miejscowościach na terenie diecezji, gdzie nie obowiązywało prawo magdeburskie, zadanie to powierzono proboszczom i miejscowej władzy.

(36) De Abusu Artificum in suis Contubernis scandaloso (k. 31) Synod postanowił zabronić rzemieślnikom gorszących praktyk związanych z dopuszczeniem czeladników do cechu: ubierania się na wzór zakonników, kropienia przyjmowanych wodą święconą i innych „bluźnierczych” obrzędów. Nakazano, aby tego rodzaju akty odbywały się w Wilnie w obecności kapelana korporacji, zaś w pozostałych miejscowościach przy udziale proboszczów, zgodnie z konstytucjami królewskimi, pod karą jednego kamienia wosku na rzecz kościoła parafialnego i pozbawienia przełożonego urzędu oraz innymi karami zarezerwowanymi burmistrzowi.

(37) De Cantus publici \& Musices prohibitione (k. 31-32) - Mając na względzie zgorszenie i zły przykład, który powodują nieprzyzwoite pieśni śpiewane na publicznych placach przez kantorów i uczących się śpiewu w szkołach obrządku greckiego, dekretem synodu napomniano uczących takich pieśni, aby tego w Wilnie i w innych miejscowościach nie czynili. Gdyby nie podporządkowali się temu zarządzeniu, nakazano ich siłą, ale „bez obrazy ciała”, doprowadzić do więzienia biskupiego dla odbycia słusznej kary.

(38) De habitu Clericali a Ministris dissidentium non deferendo (k. 32-33) - Na prośbę duchowieństwa zgromadzonego na synodzie i dla nadania większej mocy konstytucjom synodu biskupa Sapiehy postanowiono, że w przeciągu trzech miesięcy od ogłoszenia dekretów synodalnych, tj. od pierwszego października do końca grudnia, żaden z pastorów wyznania augsburskiego i kalwińskiego nie będzie nosił stroju duchownego, podobnego do tego, który noszą duchowni katoliccy, pod karą publicznego pozbawienia takiego

${ }^{10}$ Statuty synodu prowincjonalnego warszawskiego z 1643 r.: art. (38) Ne clerici saeculares regularibus Missam in suis ecclesiis cantantibus ministrare audeant. Zob. J. Sawicki, Concilia Poloniae, dz. cyt., s. 90. 
ubioru, na co w Wilnie ma baczyć dziekan, zaś w poszczególnych parafiach proboszczowie. Dla uniknięcia niepotrzebnego zamieszania, polecono unikać „krwi i gwałtu”"1.

(39) De Assistentia Matrimoniis indebita vnde nulla esse debeant (k. 33-34) - Zwraca się uwagę, iż wbrew normom Soboru Trydenckiego, które nakazują zawieranie małżeństwa wobec własnego proboszcza lub na podstawie licencji własnego ordynariusza, wielu prezbiterów obrządku greckiego a także, nad czym należy ubolewać, spośród schizmatyków, dla zysku bezprawnie asystuje przy zawarciu małżeństw i bez wygłoszenia bez trzech zapowiedzi. Synod ogłasza, iż takie małżeństwa zostają zawarte nieważnie. Przywołano w tej sprawie edykt metropolity kijowskiego Cypriana Żuchorskiego, ogłoszony w Wilnie. Dla jego egzekwowania wyznaczono kanoników wileńskich Jana Zgirskiego i Jana Piątkowskiego. Duchownym, którzy wykraczaliby przeciw prawu grozi kara suspensy a Divinis na okres trzech lat oraz inne kary kościelne.

(40) De Judaeis Familia Christiana abutentibus (k. 34) - Synod występuje przeciw niegodnym praktykom służenia u Żydów i nakazuje, aby dziekan wileński, a poza miastem poszczególni proboszczowie wraz z miejscowymi urzędnikami, karali takie przypadki zgodnie z przepisami prawa, wskazując jednocześnie na negatywne skutki takiej służby: niańki służące u Żydów łatwo ulegają ,judaizacji”, zaniedbują święta i życie sakramentalne, wystawiają się na pijaństwo i obżarstwo, nie mówiąc już o sprzedawaniu się z powodu ubóstwa i haniebnym dopuszczaniu się „zapłodnienia”, czy też narażaniu dzieci chrześcijańskich na niebezpieczeństwo posłużenia się nimi w żydowskich obrzędach „effusionis sanguinis”, o których powszechnie wiadomo, że są praktykowane.

(41) De exdiuisione \& dislimitatione Parochorum in Diaecesi Vilnensi (k. 35-37) - Zgodnie z oczekiwaniami duchowieństwa synod zachęca, aby przed powołaniem komisarzy, zostały podjęte działania w celu wyznaczenia granic kościoła katedralnego i kościoła św. Jana w Wilnie. Synod postanawia też, z uwagi na prawa kościoła katedralnego, w którym od dawna udziela się chrztu dzieciom wiernych tej parafii, odnowić chrzcielnicę zniszczoną podczas najazdu Moskwy i ustawić ją w widocznym miejscu. Ponieważ wyżej wspomniana parafia św. Jana, z racji na wielkość, nie jest w stanie dostatecznie zaspokoić potrzeby wiernych, postanowiono skorzystać z przykładu miasta Krakowa i nadać prawa parafialne kościołowi św. Stefana, kościołowi prepozytalnemu św. Józefa i Nikodema oraz kościołowi ojców augustianów. Jednocześnie ściśle określono granice ich jurysdykcji.

11 Statuty synodu diecezjalnego wileńskiego z 1669 r.: art. (32) De ministris seu praedicantibus haereticorum, ne utantur habitu clericali. Zob. J. Sawicki, Concilia Poloniae, dz. cyt., s. 90 . 